\title{
Pragmatism, identity, and the state How the Nuaulu of Seram have reinvented their beliefs and practices as "religion"
}

\author{
ROY ELLEN
}

\begin{abstract}
The Dutch colonial state categorized animists and ancestor-worshippers and inscribed them into written records in ways that have had long-term effects. The immediate post-independence period in Maluku, despite early political turmoil, settled down to a kind of stability under the New Order, the paradoxical outcome of which was both gradual integration of Nuaulu into a wider political and cultural consensus and conditions favouring economic change that undermined that consensus. The new policies of reformasi after 1998 presented further opportunities for Nuaulu to engage with the state in ways that promoted their interests. The opportunities were short-lived, however, given the implosive events of the communal unrest that lasted until 2001. This paper illustrates how this history has influenced Nuaulu self-perceptions and conceptualization of themselves as a separate people with a "religion" that goes beyond simply adherence to adat, and how this process has been partly driven by demography and a desire for pragmatic accommodation.
\end{abstract}

KEYWORDS

Nuaulu, Maluku, religion, animism, ethnicity, official categories, government policy.

\section{INTRODUCTION}

One of the consequences of the communal conflict that tore Maluku apart between 1999 and 2002 was a radical reshaping of the way in which local communities related to the state. By this I am not referring to changes in

ROY ELLEN is emeritus professor of anthropology and human ecology at the University of Kent, where he has taught since 1973 . He received his postgraduate training at the London School of Economics, and has undertaken extensive field research in Indonesia, mainly relating to environmental anthropology and ethnobiological knowledge systems. His recent books include On the edge of the Banda zone; Past and present in the social organization of a Moluccan trading network (2003, Hawaii University Press), Nuaulu religious practices; The frequency and reproduction of rituals in a Moluccan society (2012, KITLV Press), and the edited work Modern crises and traditional strategies; local ecological knowledge in island Southeast Asia (2007, Berghahn). Roy Ellen may be contacted at: R.F.Ellen@kent.ac.uk.

(C) 2014 Faculty of Humanities, University of Indonesia 
administrative boundaries, though of course there have been many, ${ }^{1}$ but rather the move from a position whereby local language, custom and geographic situation generated difference and official recognition, to a position in which religion provided the overarching and contrasting means by which communities could be identified. This could be seen during the years of reconstruction in the way that it was often churches and mosques that were among the first public buildings to be rebuilt, often more impressive than before. The Nuaulu people of Seram, ${ }^{2}$ being neither Christian nor Muslim, were in some significant respects observers of all this, though inevitably drawn into the fray through physical proximity and social relations. And although the conflict was not the only determining factor, I want to argue in this paper that what Van Klinken (2001) calls the "Maluku wars" have significantly progressed the way in which Nuaulu were beginning to reshape their own system of beliefs and ritual practices as a "religion". This process has taken place in emulation of, and alongside, other confessional groups, in a local Moluccan context, and increasingly in a national Indonesian one.

The paper is organized historically. I begin with some aspects of the colonial legacy, particularly examining how state and allied agencies pigeonholed animists and ancestor-worshippers for representational and administrative purposes, and how - if you will - they were inscribed into the textual records. I also examine the circumstances and facts relating to declining population numbers. I then move on to the immediate post-independence period, and describe how despite early political instability, there followed a consolidation of the peace, the main outcome of which was the gradual integration of Nuaulu into a kind of political and cultural consensus under the New Order. Paradoxically, this consensus also provided precisely the right conditions for the forces of economic change that undermined that consensus (extensive in-migration, logging, infrastructure development, extension of the labour market). This phase culminated with the "threefold crisis" (Schulte Nordholt 2002) of 1998

1 From what had been the province of Maluku before 1998, two new provinces were created: Maluku (the old regencies (kabupaten) of Kota Ambon and Maluku Tengah) and Maluku Tenggara. In 1999 the northern part of Maluku (then comprising the Maluku Utara regency, the Halmahera Tengah regency, and Kota Ternate) were split off to form a separate province of North Maluku. The new province of Maluku was divided into 11 regencies. From the old kabupaten of Maluku Tengah, four new kabupaten were created: Seram Bagian Barat, Seram Bagian Timur, Buru Utara, and Buru Selatan. In 2013, the new kabupaten of Maluku Tengah comprised 14 subdistricts (kecamatan). The old Amahai subdistrict had been split into three: Teon Nila Serua, Amahai and Teluk Elpaputih. The kecamatan Teon Nila Serua had been established somewhat earlier (before 1994) from the territory of the old Amahai subdistrict to accommodate migrants from the southwest islands of the same name, who had been displaced for environmental reasons.

In addition, according to maps and lists produced at the kabupaten and kecamatan level, there have been various changes in the boundaries of desa (village) jurisdictions between 1970 and 2009. Since maps produced for administrative purposes are rarely precise in terms of desa boundaries, there has been much scope for confusion and disputation. What is more, traditional polities such as Sepa have often contested boundaries, such that the new Nuaulu villages, despite being in the Ruatan Transmigration zone, remain part of this jurisdiction.

Animist Nuaulu currently occupy six settlements in the kecamatan of Amahai. 
and the consequent policies of reformasi (reformation) and otonomi daerah (local autonomy). These latter presented further opportunities for the Nuaulu in terms of their engagement with the state, but were rapidly followed by the implosive events of the communal unrest that lasted until about 2001. I shall try to assess how the conflict itself and the period of post-conflict reconstruction up to 2009 has influenced Nuaulu self-perceptions and conceptualization of themselves as a separate people with a "religion" that goes beyond simple adherence to adat (meaning here customary law and ritual practices). I argue that much of this is driven by demography and a desire for pragmatic accommodation.

\section{COLONIAL CATEGORIES AND THEIR CONSEQUENCES}

Classification of subject peoples by religion was a standard feature of administrative reports and documents produced by officials working in the Groote Oost (The Great East) of the Dutch East Indies during the colonial period. Christians, Muslims, Heathens, and others had been living together in the Moluccas since the sixteenth century, ${ }^{3}$ and by the seventeenth century their enumeration had become routine (Knaap 1991). The wars of the late seventeenth century, chronicled by the VOC historian Rumphius, show how local populations split along confessional lines and were often relocated in ways that find an echo in the "Maluku Wars" of the early twenty-first century, differences reflected also in present-day language distribution. ${ }^{4}$ By the 1680 s (Rumphius 1910) the polity of Sepa on the south coast of central Seram was still 80 percent animist "Alifuru", though since at least the mid-century both Sepa and Tamilouw (in the same language group, but politically autonomous and ten kilometres apart) were in the process of conversion to Islam. At this time, Sepa and the Nuaulu clans were in alliance against Tamilouw, the few Christians in Sepa and the Dutch. These historic events are said by adat authorities in present-day Sepa to underpin the present alliance between Alifuru Nuaulu and Muslim Sepa (Ellen 2004: 55). Many of the new Christian communities in parts of the Moluccas established during the seventeenth century did not survive and there was extensive reversion to traditional beliefs (Bartels 1979: 288), while (outside of Ambon) the Christian population of the Moluccas was to grow only gradually until the nineteenth century.

Both published and unpublished reports from the mid-nineteenth century onwards regularly include figures by administrative district of remarkable (though perhaps therefore inevitably doubtful) precision. For example, up

3 The early history of Christian conversion, by the Portuguese to Catholicism, is documented by Schurhammer (1963: 663-665). By all accounts, the Portuguese were very successful in converting non-Muslims to Catholicism, outside of inland and upland Seram. After 1605 there was a transition from Catholicism to Protestantism under Dutch Lutheran influence (Bartels 1979: 288).

4 The now separate villages of Sepa and Tamilouw (Muslim) and Hatuheno (Christian) share the same language, as do Rutah and Amahai (Muslim), and Makariki and Soahuku (Christian) (Atlas bahasa tanah Maluku 1996). The language of Nuelitetu spoken in a village near Sepa until 1996 was a relic of an earlier population movement by Wemale people (Collins 1982: 106). 
until the administrative reforms of the late nineteenth century, the Nuaulu area of Seram (Figure 1) came under the afdeling (division) of Saparua, and Bleeker (1856: 207) tells us that of a total population of 24,194 in 1854, 5379 were christenen (Christian), 5763 mohammedanen (Muslim), and 13,050 heiden (Heathen). Elsewhere he uses the term alfoeren for the same category (for example, p. 208), and indeed this term or its cognates (alifures, alfuros, alifurus, alfoer) is so widely encountered in the literature from the earliest Portuguese accounts (Schurhammer 1980: 69; Galvão 1971: 367), that I will here use contemporary Ambonese Malay alifuru to refer to those groups generically and to individuals who have converted neither to Christianity nor Islam. As we shall see, the term has developed a more complex multi-facetted set of meanings in the context of Moluccan ethnic politics of the twentieth and twenty-first centuries. ${ }^{5}$

The categories adopted in the statistics, however, are not exclusively religious. "Alifuru" itself is not a specifically religious designation but implied heiden, while christenen, mohammedanen, and heiden/alfoeren, are regularly augmented with Europeanen, Chinezen, Arabieren, and slaven (see for example, Bleeker 1856: 208), the latter (slaves) being generally Papuan, or at least largely non-Moluccan by the mid-nineteenth century. ${ }^{6}$ We must infer from these implicit contrasts that christenen therefore refers to indigenous ("native" or Dutch inlander) Christians and mohammedanen to indigenous Muslims, rather than to incomers from other parts of the archipelago or outside it. Thus, the classification is simultaneously polythetic and quasi ethnic.

In late nineteenth and early twentieth century maps too, villages were often shown with an icon displaying either a cross or a crescent to denote Christian and Muslim villages respectively, as in Karl Deninger and Otto Taurn's German language map of Seram produced in 1914 (Deninger 1914), which separates Mohammedanisches villages from those with a Christian teacher. In earlier Dutch maps (for example, Van Hoëvell's "Schetskaart van Oost-en Midden Seran" of 1896), only Christian villages are indicated with a special icon (Figure 2). Thus, in graphic representations (though not in the statistics) those adhering to traditional Alifuru practices were often invisible, while in the Van Höevell map unmarked villages (that is both Muslim and Alifuru villages) become part of the default "other", implying that they were either yet to be converted (to Christianity) or problematic to administer. Either way, the forms of inscription support the notion of some kind of default "pagan elsewhere" constructed through the European colonial imagination (Spyer 2000: 68).

5 The term Alifuru is inevitably problematic itself, having become - like so many ethnonyms for low status groups (for example sakai, kubu) - a term of abuse, even used by Nuaulu (Alifuru) mothers when chastising their children. A term with similar connotations to Alifuru is kafir, apparently used by traditionalists in Nusa Tenggara as an acceptable form of self-identification (Keane 1995: 291).

$6 \quad$ For the earlier period slaves in Ambon are listed as Javanese. By the nineteenth century they were largely Papuan, though in some areas there were traditions of taking slaves from Seram (Ellen 2003: 139-41). 


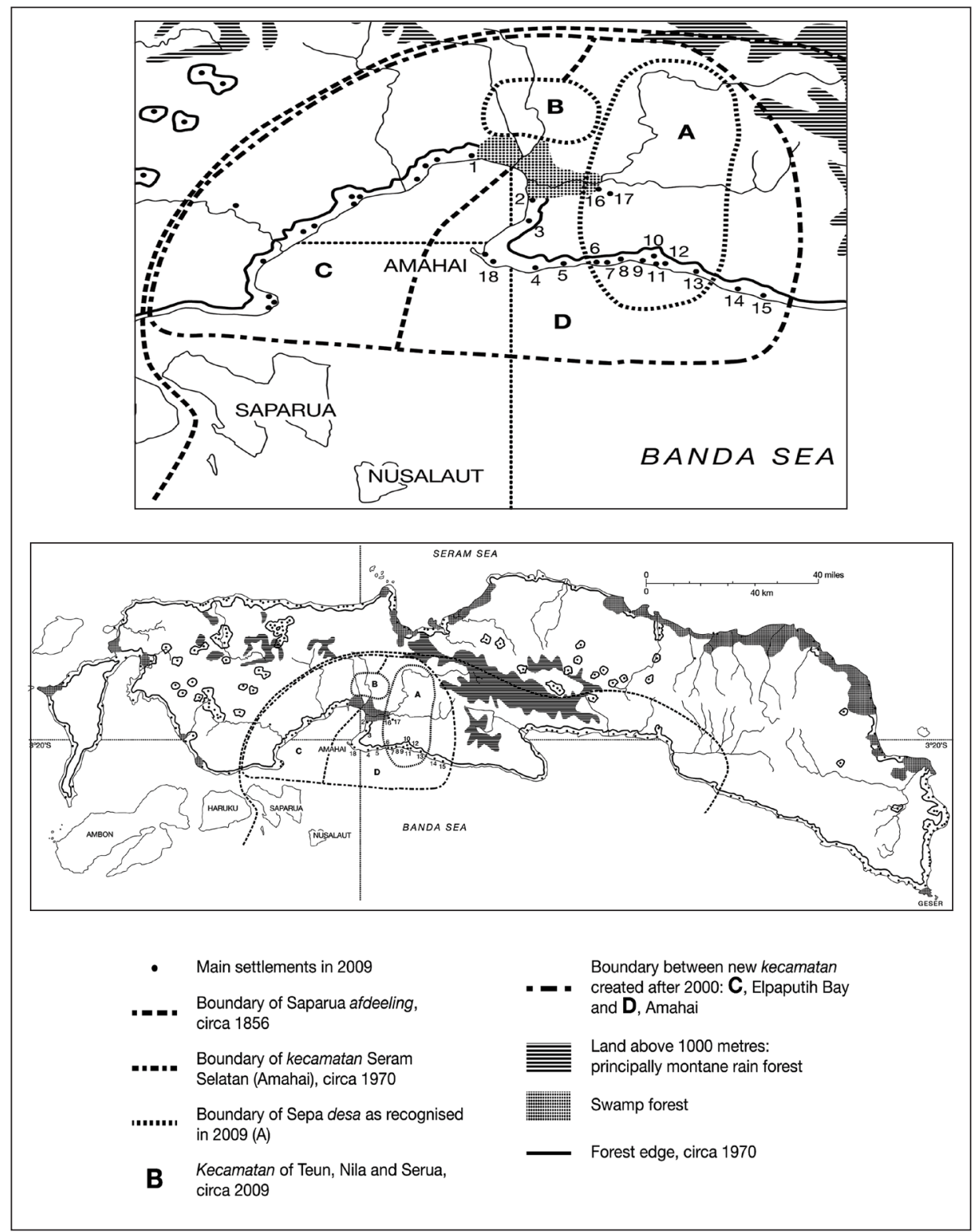

Figure 1. Map of Seram showing location of Nuaulu and other places mentioned in the text, and indicating some relevant changes in administrative boundaries between 1856 and 2009. Key to numbered settlements (Nuaulu settlements in italics): 1, Waraka; 2, Makariki; 3, Masohi; 4, Rutah; 5, Yainuelo; 6, Hatuheno; 7, Nuelitetu (abandoned); 8, Bunara; 9, Niamonai (Watane); 10, Aihisuru (abandoned); 11, Sepa; 12, Hahualan; 13, Rouhua; 14, Tamilouw; 15, Yalahatan; 16, Simalouw; 17, Tahena Ukuna; 18, Soahuku. Map adapted from Topographische Dienst 1921, Eiland Seran en omliggende eilanden, Netherlands. Boundary data from field notes, Bleeker 1856, and Kantor Wilayah Kecamatan Seram Selatan 1993. 


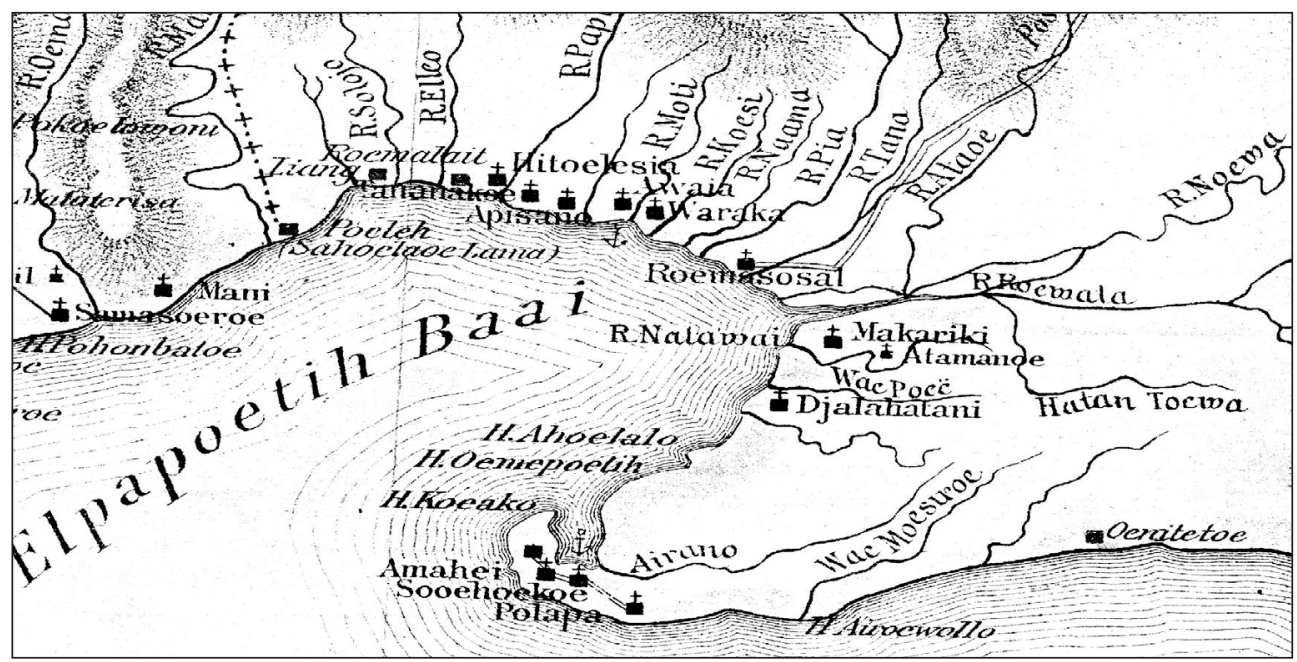

Figure 2. Extract from "Schetskaart van Midden Seran" (G.W.W.C. Baron van Hoëvell 1896), at a scale of 1:250,000. Note representation of Christian villages with a cross $(\dagger)$, but no religious differentiation of other villages.

Part of the explanation for this apparent official invisibility of Alifuru groups was related to their location. They were often in the mountains rather than on the coast, and generally living in dispersed small settlements (sometimes constituted as a single "house" or clan [soa, ipan] group), compared with the highly nucleated and largely coastal Muslim and Christian villages. In fact, as mountain groups in west and central Seram converted to Christianity they were often under pressure from the Protestant Nederlandsch Zendelingengenootschap (Dutch Missionary Association), and later the Gereja Protestan Maluku (GPM), to move to the coast and to nucleate. Alifuru groups who did not convert were also subject to this pressure, as part of a government strategy to establish rust, order, en belasting (peace, order, and taxes: see Kennedy 1955: 121). This pressure was often exerted through coastal rajas with traditional links with inland Alifuru groups. Thus, Nuaulu clans appear to have first settled around the Muslim kingdom of Sepa at the time of the administrative boundary and local government reforms of the 1880s. While there were often advantages for inland animist groups in moving to the coast (for example, access to markets, health, and educational facilities), there was also resistance, particularly where the conditions involved compromising matters of adat. Thus, Tichelman (1960) reports the setting up of "Potemkin villages" 7 around Sepa, with (often empty) official houses nearer the sea arranged geometrically in grids with bamboo fencing according to government

The phrase "Potemkin village", from the Russian Potyomkinskiye derevni is widely employed either literally or figuratively to refer to a fake settlement or other construction built to impress and deceive people into thinking that it is other than it is. It alludes to Grigory Potemkin who during the Crimean military campaign of 1787 erected fake villages along the banks of the Dnieper to fool Catherine II during her visit to the front (Smith 2005). According to Sebag-Montefiore (2000) the story is largely fictional. 
stipulation, while retaining separate villages further inland and on higher ground that better met the spatial and symbolic adat requirements.

As we have seen, by the late nineteenth century, there were still large numbers of animist Alifuru on Seram. In the middle part of the century the Dutch military embarked on a campaign (1860) to crush the Alune and Wemale in west Seram. Attempts by the government to suppress kakian initiation rites, of which head-taking was an intrinsic part, led to rebellion (Van Rees 1863), with further unrest following government attempts at economic exploitation (Polman 1982:164). These episodes were partly instigated by a perceived threat of enforced conversion. The same issues persisted into the twentieth century, and there was another campaign in west Seram in 1914-15 directed against the kakian, also exacerbated by fears of forced Christianization (Kruisheer 1928; Polman 1982: 166). The trouble however, was not confined to west Seram, and there was intermittent trouble in central Seram as well from the 1860s (Polman 1982: 164). Muslim rulers, particularly along Seram's north coast resisted the onward march of mission activity in areas they regarded as their domain of influence (Krayer van Aalst 1911). Although west Seram had been largely pacified by the time of the Frobenius expedition of 1937-1938, a KNIL (Koninklijk Nederlandsch-Indisch Leger) post was still maintained in Wahai until much later. However, there are few references in the Dutch colonial archives to the Nuaulu, and pacification and the government remit would appear to have been established in the Amahai subdistrict in a more orderly fashion than in many places (Kelling 1888; De Vries 1875), with the Indische Kerk involved in the deliberate dissemination of what were regarded as "Ambonese culture elements". 8

Another problem faced by the colonial government was how best to describe Alifuru groups and fit them into an administrative framework. Ways of talking about the beliefs and practices of such people were problematic. Heidenen was essentially a religious description used by the churches and did not capture any particular discriminating features. Moreover, it was essentially a default category, into which was placed what did not fit in the other more clearly definable categories. It may have been in part for this reason that the practice of describing Moluccan Alifuru as "Hindu" (on the analogy with Balinese Hindus) was adopted. As we shall see, this solution to a question of categorization had interesting and problematic consequences for Nuaulu in the post-colonial period.

Alifuru official invisibility was further accentuated through the development of a system of adatrecht administration under the influence of Van Vollenhoven during the late colonial period (Ter Haar 1948; Henley and Davidson 2007: 2, 19-21; Holleman 1981) that cut across religious difference, and was the primary form of administering law. Unlike the British in Malaya, who were content to see adat subservient to Muslim syariah, it was convenient for the Dutch judiciary in the East Indies to adopt a legal system based on

8 There was conflict between Protestant and Catholic missions as Catholic evangelical activity spread to Seram after 1890 . 
regionally distinctive adat laws which locally, at least in theory, cut across religious difference. Such an arrangement served the interests of colonial state-building in treating the syariah as secondary, and provided a buffer against the kind of Islamic-inspired insurrection that had preoccupied the Dutch in Aceh during the 1870s (Ellen 1988a: 51-52). Thus, the Netherlands Indies became a carefully-cultivated "zoo of difference and of differences" that paradoxically aided effective social control (Appadurai 1996: 117-118). Such a system of legal administration was politically convenient also for the first two governments of independent Indonesia, with their secularist and developmentalist nation-building agenda. However, reflecting the diverse ways in which adat is itself locally constituted in different parts of the country, the state has often been "ambiguous and incoherent in its recognition of adat laws and rights over land and other natural resources" (Moniaga 2007: 279), an attitude rooted in the ideological legacy of Indonesian nationalism (Henley and Davidson 2007: 18).

Under Dutch rule, Christians in the central Moluccas were privileged and Muslims marginalized. Christians were more likely to enter government or religious schools teaching written Malay and Dutch, and more likely to graduate with higher attainment levels. As a result, Christian Ambonese tended to dominate the lower levels of the civil service and the KNIL from the last quarter of the nineteenth century to the end of the colonial period, leading to tension with the Muslim community. Differences in access to resources between Muslims and Christians accentuated between 1942 and 1945 as a deliberate result of the policy of the Japanese occupation, as did "the parallel processes of Islamicization and Christianization [established] in the wake of World War II and the related erosion of the common ground of 'custom' or adat shared by Ambonese" (Spyer 2002: 23).

\section{THE DEMOGRAPHY OF ANIMISM}

Thus, throughout the colonial period what Appadurai (1996: 118) has called "enumerative strategies" were an important part of the "rhetoric of number and accounting" (Spyer 1996: 192). Whatever the various purposes to which population figures are put they are, as Spyer (1996: 191) reminds us "rarely gratuitous", contributing to an elaborate representation of the topography of cultural difference, and to the envisioning of those described in the Moluccas as Alifuru. Although Dutch missionaries experienced severe difficulties in effecting conversion even in the first decades of the twentieth century, by the end of the colonial period the number of animists had been reduced to a small number, with clans and "houses" often insufficiently large to viably reproduce their collective ritual practices. Despite the instability of the immediate postcolonial period in the Moluccas, this downward trend in numbers continued.

If we examine the 1983 population figures for Seram as a whole, about $67 \%$ are recorded as Muslim, well over half of which were distributed between the subdistricts of West Seram and East Seram. Official figures at this time place the number of animists at a mere 312. If we confine ourselves to those individuals 
who self-report as animists (represented by terms such as animisma, suku adat, and Hindu) - that is, ignoring the large number of persons effectively engaged in various animist practices alongside formal confession to a canonical religion - this is likely a considerable underestimate. Placing Alifuru in the alternative neutral census category of lain (other) also tends to conceal real numbers and perpetuates their official invisibility (compare Keane 1995: 291, fn 8).

Looking at central Seram alone, the number of animist Huaulu in the Manusela area reported by Valeri for 1969 is 139 (Valeri 1980: 180), a number hardly viable for the reproduction of most traditional rituals (Ellen 2012: 292, 296). However, by contrast, south-coast Nuaulu numbered 496 in 1970, and I estimate that since then the population of Nuaulu animists has more than tripled (Ellen 2012: table 9.2). For example, in 1971 the population of Rouhua village was 180, which included no more than two or three Christian households. Muslim converts, of whom there were a few, had moved out of the village altogether, as had some Nuaulu who had married Christians. By 1998 the overall figure for Rouhua had risen to 624 inhabitants, 350 of whom were animists. Of the 147 Muslims, most were incoming Butonese, a few of whom had married animist women. The 100 Protestant and 27 Catholics were all Nuaulu converts. Taking into account raw data from the 2003 census, we obtain a total figure of 2,200. Since the year 2000 the population has increased still further (Ellen 2012: 294). These numbers are small, and it might be thought so small that serious arguments can hardly be constructed on the back of them. However, demographics are important, even of clans, both because they underpin the viability of reproducing a sustainable ritual community (Ellen 2012), but also because growth in numbers has given Nuaulu confidence to assert their identity in new ways. The Nuaulu have, therefore, bucked the trend of animist decline, and the reasons for this and its local consequences are worth further examination.

\section{THE CONTRADICTIONS OF THE POST-COLONIAL CONSENSUS}

The general trend in terms of Nuaulu religious change during the post-colonial period continued what had begun during the Pax Neerlandica and under the auspices of the Muslim Raja of Sepa: a process of routinization, accommodation, and "domestication" of ritual, conveniently summarized in the assertion that Nuaulu religion had become one of "plates and red cloth". This was well before the advent of what we might describe as "Pancasila pressure" (about which more later). The most obvious alteration was in relation to the suppression of head taking, hitherto an essential ingredient of the ritual process. But changes also occurred that reflected a newly-shared Indonesian culture of modesty, self presentation and norms of acceptable public interaction, and that truncated and simplified ceremonies and their organization in ways that fitted the convenience of new economic and political necessities. Such accommodation has also taken a more subtle and bureaucratic form, as Nuaulu have been drawn into the world of education, politics and electronic media that potentially places them in touch with people of their own kind (masyarakat adat) elsewhere in the country. 
The beginnings of the post-colonial period in Maluku were occluded by the almost immediate attempt by a large segment of the population to secede from the new republic (Chauvel 1990) and establish a Republik Maluku Selatan (RMS). This in large part reflected the sentiments of Christian Ambonese, though found support among some Muslims, and (relevant to my argument here) tapped into the autarkic predisposition of the remaining Alifuru populations. Although an autonomous republic was declared in 1950, the Jakarta government was able quickly to reassert its authority in Ambon, though the cause was sustained in remnant form for several decades within the Ambonese diaspora in the Netherlands, while local separatists were able to operate a guerrilla campaign in the interior of Seram until around 1964-5 (Van Fraassen 1983: 36). During part of this period, some Nuaulu provided paramilitary support as RMS irregulars active in the central mountains of Seram. What gave this alliance cultural validation was the belief promulgated by some ideologues that in ethnic and racial terms Moluccans had more in common with Papuans than with Indonesians, and it was Alifuru cultural practices that gave "anthropological" credence to such Pan-Melanesianism (Bouman et al. 1960). ${ }^{9}$ Indeed, some Nuaulu (for example, Hatuniasa Sounaueainakahata) had emigrated to the Netherlands where they had made common cause with the RMS in exile. Some 20 years later, shortly after the notorious 1975 Moluccan hijacking at Wijster in the Netherlands (see Van Kaam 1977), I had received a deputation of second generation Moluccan youths from Groningen hoping that I might make contact with Nuaulu acquaintances with a view to providing "signs" as to the whereabouts of the legendary RMS leader Christiaan Soumokil, who had officially been reported executed in April 1966. However, by the late 1960s the RMS threat had receded on Seram itself, and although there was local sympathy in some areas, and in theory the rudiment of an alternative government in waiting, it was not to become a significant factor again until the communal unrest 30 years later.

The first ten years of my fieldwork on Seram, beginning 1970, were years of apparent stability in terms of settlement, and of modest Nuaulu engagement with the government and the market. Nuaulu had been designated by the Department of Social Affairs as suku (later masyarakat) terasing (remote peoples). This afforded them some protection and access to "development" resources, but arguably froze their derogatory status as suku yang masih terbelakang (groups that are still backward), and also gave them the wrong kind of attention. But, from 1980 onwards, important changes began to take place that would transform Nuaulu relations with the outside world: increased schooling, in-migration and the expansion of logging activity. A hitherto poor transport infrastructure began to expand with the extension of the network of metalled roads and vehicular access (Ellen 1999). These changes also increased the potential for conflict and modified Nuaulu self-perceptions of their own

9 In the context of the 1998-2002 troubles, the Front Kedaultan Maluku (FKM, Front for Moluccan Sovereignty), the successor organization to RMS, once again sought to bring about "a nostalgic resurrection of an indigenous 'Alifuru' Moluccan identity" (Spyer 2002: 26). 
beliefs and practices.

Prior to 1970 there were only a handful of Nuaulu individuals who had attended elementary school and who had attained basic literacy, most notably Marapati Sounaue-ainakahata (otherwise known as "Merpati"). Marapati, born in 1939, first became government head of the Nuaulu settlement of Niamonai outside Sepa, and subsequently (in 1980) head of the new settlement at Tahena Ukuna. In Rouhua, Sekanima Neipane-tomoien, born 1942, also had basic literacy. During the early 1970s a major decision had been reached in several Nuaulu villages about the importance of schooling (hitherto resisted), and a group of children began to attend the elementary school in Sepa. By 1998 there was a permanent teacher in Rouhua, and a school attended by most children 0.5 kilometre east at Perusahaan (company), so-named because it was built on the site of an old Filipino logging camp near a creek that Nuaulu themselves call Samna Ukuna.

The period 1970-1980 saw the first major influx of transmigrants into Seram, and by the early 1980s this was becoming important in the Amahai subdistrict. In addition, there was "spontaneous" in-migration of non-local Butonese to the Sepa area. These migrants (Ellen 2012: 301) tended to arrive as individual families and settle in the Nuaulu areas through a process of negotiation with the desa of Sepa and the relevant Nuaulu village and clan heads. They bought or rented Nuaulu land and, although there was some friction over resource issues and the building of a prayer house, a modus vivendi was established, with settlers adopting some Nuaulu customs and subsistence practices and generally respecting their traditions. The situation with the government migrants in the transmigration zones was very different. While there was some degree of acknowledgment that the zones themselves were created on Nuaulu traditional land, and Nuaulu were compensated financially and in kind by being offered plots and houses at various designated locations along the Ruatan valley, the relations established with particular groups of newcomers have not always proved to be smooth, particularly with Christian settlers from the nearby islands of Ambon, Haruku, Saparua, and Nusalaut.

Road construction and transmigration brought Nuaulu closer to lands they had inhabited and actively extracted from before the eighteen-eighties. As a result, Nuaulu abandoned some of their long-existing settlements, including the important ritual settlement of Aihisuru, and established new settlements in the Ruatan transmigration zone, particularly at Kilo Sembilan and Kilo Duabelas, the Nuaulu sections of which were Simalouw and Tahena Ukuna respectively. Cash crop planting began in 1980, and the first permanent residents of Simalouw arrived in 1983. By 2003 there were over 56 Nuaulu households in the transmigration area as a whole (Ellen 2012: table 9).

During the same period, logging operations had come ever closer, with economic and social consequences (Ellen 1999). The neoliberalism of the New Order encouraged a market in land, under pressure from logging companies, and the Nuaulu were drawn into this, often with problematic consequences. In 
a case reported to me in 1990, land "sold" to the government at Kilo Duabelas, was then resold to people from Makariki. The dispute went to court, and the Nuaulu involved lost the case. There were disputes as well with Sepa over land along the south coast at around the same time, which encouraged Nuaulu to move to the Ruatan area. Nuaulu residents at Simalouw also sold land to small logging companies in the Makariki area, and to incoming Butonese. Such transactions, despite the difficulties, reflected informal local customary recognition of Nuaulu access rights to forest despite the national legislation in place at the time (see also Moniaga 2007: 289). Nuaulu subsequently experienced problems with the environmental impacts of logging operations, but most conflict tended to be with other Nuaulu clans about who had the rights to alienate land, or with transmigrants over - in particular - sago swamp forest. Rapid social change and an increasing pressure on resources and various issues over land after 1990 culminated in outbreaks of violence with transmigrants and two incidents of head-taking (1993 and 2005), after 50 years of apparent abstinence. The first of these occurred well before the outbreak of wider communal conflict in 1998.

The 1993 event received a lot of distorted publicity at the provincial level, and I have been able to show elsewhere (Ellen 2002) that whatever else this episode tells us about the latency of head-taking beliefs, it had at its roots a quarrel over resources, in this case regarding access to sago groves between people from Rouhua and Christians from Saparua. The events influenced ritual practice more directly, since the decapitated heads that were returned to the village had to be dealt with in the context of a "semantically depleted" tradition and led to some rapid reformulation of appropriate ritual management, in this case burying the heads in the post-hole of the north-east corner of a clan sacred house. At the time, and certainly during my subsequent field visits of 1996 and 2003, it was assumed that this was a one-off incident erupting as some kind of cultural default mechanism or aberration, and that, as Saete had told me, Nuaulu are now "a religion of plates and red cloth". However, in July 2005 a second incident occurred, this time not involving Nuaulu from Rouhua, but instead, from Tahena Ukuna. Both incidents reflect Nuaulu existential angst as to their vulnerability as a group, not only a material vulnerability, but also a fear that their ritual cycles will not be reproduced (Ellen 2012: 302). While we may be persuaded that these events constituted a relapse rather than reversion, they served to reinforce the earlier Dutch and Ambonese primordialist stereotype of the interior peoples of Seram as alifuru and primitif (in this sense, "savages, primitive"), ironically converging with images of Nuaulu promoted through the local ethnic tourism industry (compare Figures 3). Some of the more gruesome depictions on the walls of Mus Tamaela's "Galeri Alifuru" in Soahuku were included in the 1997 Ray Mears' World of Survival film broadcast as popular entertainment on BBC television. 

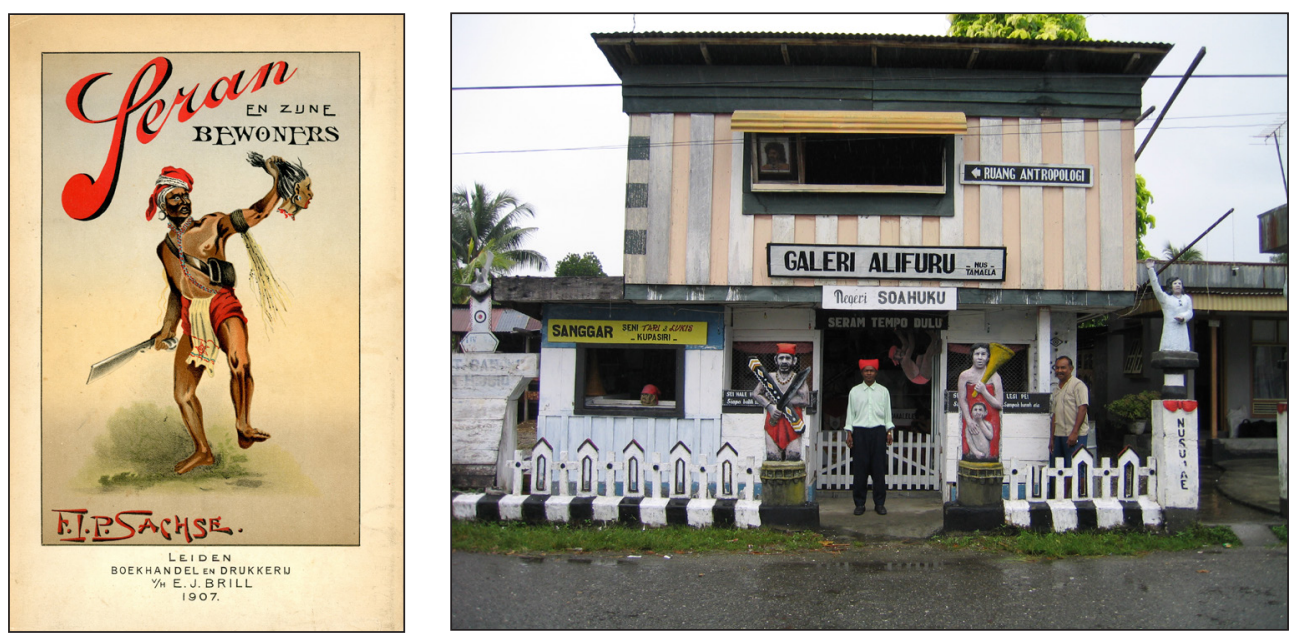

Figures 3. Comparison of two representations of Seramese Alifuru, colonial era and postindependence. Left: Front cover of F.J.P Sachse, Het eiland Seran en zijne bewoners (1907); Right: The "Galeri Alifuru", an ethno-tourism shop in Soahuku, near the subdistrict administrative centre of Amahai, 22 August 2003. The figure in the foreground is Kaiisa Neipane-tomoien, at that time serving as government head of Rouhua village. Note that similar statues and images had been displayed in Soahuku since at least 1986.

\section{AGAMA NUNUSAKU AND CUSTOM MYSTICISM}

An ideological claim that found support between both those who supported the RMS ideal (including the diaspora in the Netherlands), and those who opposed it, was that all (at least central) Moluccans shared a common culture that cut across the divisions of religion, ethnicity, and politics. This worldview became important in the post-RMS revival of adat (Bartels 1979: 294) that underpinned the stability and material progress achieved under the New Order, and in the reconciliation process that followed the conflict from 1998 to 2002. The view was typified by self-conscious cultural arrangements for mitigating differences between communities, for example pela 'blood brotherhood' (Bartels 1977) and the siwa and lima confederations (Valeri 1989), which linked villages of different religious affiliations. These were in addition to shared social institutions of cooperation, such as babalu food exchange systems and sasi that became in the 1990s an iconic Moluccan institution for the participatory and sustainable management of natural resources (Zerner 1994).

In its more extreme version, these practices have been associated with a syncretic collection of beliefs and customs sometimes described as Agama Ambon 'the religion of Ambon', or (sometimes ironically) Agama Nunusaku 'Nunusaku Religion' (Bartels 1977, 1978, 1979, 2003), ${ }^{10}$ alluding to the

10 The idea, whereby a religion is defined by geographic parameters, is reminiscent of the Weberian use of "the religion of India" or "the religion of China", particularly as reflected in Geertz's development of the idea in his Religion of Java. But in all these cases place is always qualified culturally, and in syncretic Protestant 
widespread underpinning belief that all central Moluccans have a common origin in the mythological mountain of that name in west Seram. Such ideas were consistent with a general revival of adat in Ambon during the 1970s. Beliefs regarding the role of ancestors and spirits, common healing techniques, kinship-based food prohibitions, wedding rituals, tiga malam rituals (the "three day" ceremonies following death), emblematic dances such as cakalele and maku-maku, and the persistence of traditional notions of power (Bartels 1979: 290), all played a part in this. Most importantly, they provided a bridge across the religious divide between Muslims and Christians. In such a worldview, adat is in partnership with religion rather than opposing it.

In addition to the apparent ease of movement across religious boundaries, the idea of a shared community of belief and practice is evident in the presence and influence of what Michael Scott (2011) calls "custom mystics". These are individuals, not necessarily adat specialists or people in formal religious positions, who volunteer to others, including passing anthropologists, a kind of cultural logic that supports the idea of (what I shall continue to call here for shorthand purposes) Agama Nunusaku. Several persons who could be described in this way have volunteered their services to me as cultural interpreters over the years, or simply responded to my questioning in ways that have evoked mystical casuistry. I think the term "custom mystic", with its connotations of those who seem to have a "compulsive need to interpret and mine just about everything for hidden meaning" (Spyer 2002: 35) is highly appropriate. Bartels (1979: 285) has suggested that the notion of kunci (key) is often used by such individuals as a rhetorical device to "unlock" esoteric knowledge that connects the habitus of Muslims, Christian - and Alifuru. The key role of Alifuru in this is exemplified in the expectation that I would be able to "read" the signs in the Nuaulu video brought to me by the young Moluccan activists from Groningen in the Netherlands (see above). It is also there in the "elder sibling-younger sibling" rhetoric used to explain the relationship between animist Nuaulu and Muslim Sepa, and evident in the publicity accorded certain individuals such as the Kewang Kissaya who played a leading role in the Haruku sasi movement. However, my best example of this - though I suspect a rather atypical one - is an individual who I met in Ambon in 1969 and who subsequently corresponded with me over a period of five years sending postcards and letters displaying folk-structuralist diagrams, in which the imagery of Islam and Christianity was intertwined through complementarity and symbolic integration, supported with copious references to apposite biblical verses and Koranic surah (Figure 4).

Agama Ambon there is not always space for - say - Chinese Christians (Bartels 1979: 288). 


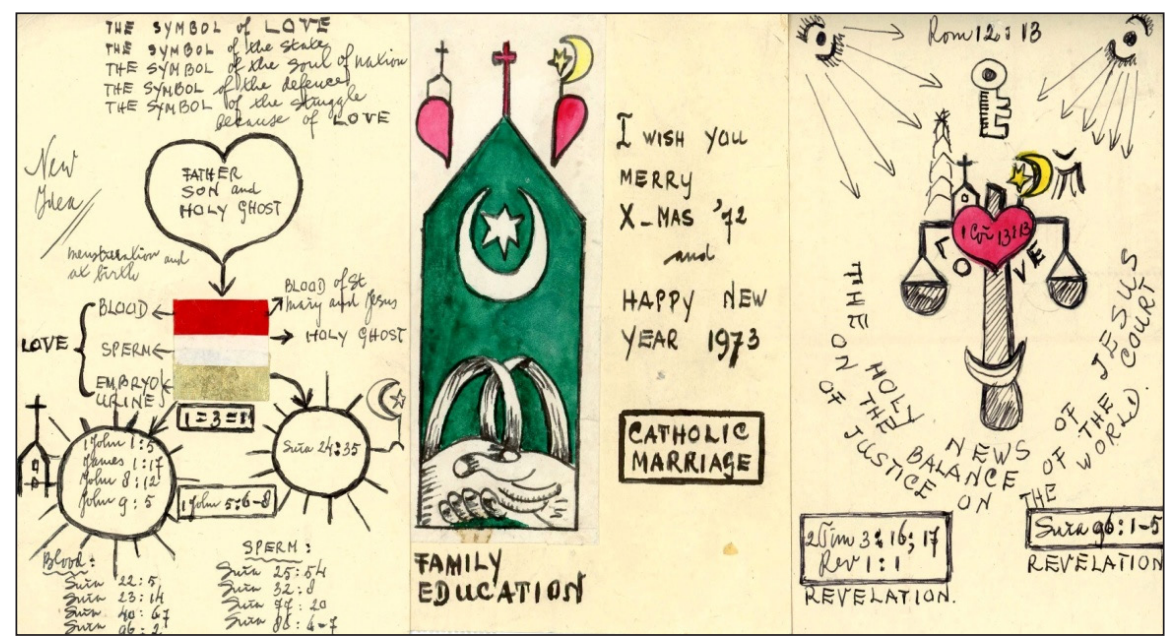

Figure 4. One person's representation of how Pancasila and Agama Nunusaku might mystically connect. Coloured inks and paper montage on postcards. Thanks to Daan Nendissa for permission to reproduce.

In the Netherlands, such mystical and quasi-millenialist ideas helped tie together some disparate elements of the Moluccan diaspora and to entrench their unrealistic political dreams, but in post-independence and post-RMS Indonesian Maluku, the same shared syncretic notions could also be used by the government and local communities as part of the process of healing. The post-Independence national political consensus, both that sort under the guided democracy of Soekarno and that sort under Suharto's New Order, was predominantly secularist and tolerant of religious and cultural diversity, while governmentally authoritarian and intolerant of inconvenient political diversity. Either way, we can see Agama Nunusaku not so much as a selfconscious traditional syncretism with deep historical roots but rather as a twentieth century creation: an outcome of the ideological wars accompanying, first, the independence movement, then the RMS secessionist movement, and thereafter the need for the Indonesian administration to achieve communal integration. In Indonesia generally, appeals to shared cultural features, comprising what Tania Li (2007, following Laura Nader, 1991) calls "harmony ideologies", have been commonly appropriated in the national interest. ${ }^{11}$ Celebrating diversity as "cultural spectacle" (Acciaioli 1985; Henley and Davidson 2007: 15) paradoxically defuses the political implications of such diversity, a strategy widely employed elsewhere by twentieth century authoritarian and totalitarian regimes (for example, Donahue and Habeck 2011; Gladney 2003; Shay 2002).

If the idea of Agama Nunusaku echoed the state motto of "unity in diversity" (Bhinneka Tunggal Ika), Nuaulu and similar pro-adat populations could be seen as guardians of the essence of this tradition. I have already referred to how Nuaulu and their Muslim neighbours in Sepa have long described their

11 The most celebrated case is perhaps gotong-royong (Koentjaraningrat 1967: 394-97). 
relationship as one between older sibling (Nuaulu) and younger sibling (Sepa), and Nuaulu mythic ownership of the land is still acknowledged in Sepa adat, even though formal secular political authority has been ceded to the Raja of Sepa in his capacity as kepala desa (village headman). Tolerance and flexibility at the local level was assisted by a heterodox set of local Muslim practices and beliefs, in which ritual and healing services were regularly exchanged across religious boundaries, and in which Christian women living in Nuaulu villages were expected to respect rules relating to menstrual seclusion.

Such three-way relations, as between Muslims, Christians, and Alifuru were also found in more formal imagery. Thus, whereas in Ambon during the communal unrest of 1998-2002 "red" was reinforced as the Christian colour and "white" as the Muslim colour, in south Seram "red" is indubitably Alifuru, "white" Muslim and "black" Christian. In certain Nuaulu rituals, for example, those involving completion of the suane (village sacred house) cycle - and at which many outsiders of other faiths are present - it is mandatory for pennants in each of these colours to fly from the ridge of the newly completed structure as part of "topping-out". Pela too is important for Nuaulu in cutting across the religious divides, but it especially links distant villages. In 1986 Sepa and the Nuaulu villages had pela relations with Lisabeta, Kamarian, Tihulale, Rumakai, Siriwan, and Kaibobo. Other more local alliances also serve to reinforce a common cross-religious identity. Before 1999, both Christian and animist residents of Yalahatan assisted in the building of the new mosque in Tamilouw, while during the 1970s Nuaulu visitors to north Seram helped build a mosque in Rumah Olat (Ellen 2012: 308). I have described some other aspects of how Nuaulu participate in the rituals of other religions elsewhere, and how non-Nuaulu reciprocally participate in Nuaulu rituals (Ellen 1988b). Similarly, the "interreligious conviviality, hospitality, and sharing" (Spyer 2002: 27) of the key holy days of each faith - usually Christmas and Eid ul-Fitri - in normal times reinforce the sense of shared community, as do the heterodox elements in traditional Moluccan Islam, such as widespread non-performance of hajj to Mecca and veneration of local shrines. This is an ethnoscape in which in particular places world religions seem to operate like local religions (Hefner 1993: 15).

\section{FLUID CONVERSION AND DYNAMIC RESISTANCE}

This paper is not the place to tease out all the features of whatever Agama Nunusaku might be, but there are aspects of the imagery that help to progress its main arguments. One such is the way the claim for an over-arching and encompassing set of beliefs makes it easier to ask fundamental questions of religious identity and to facilitate conversion. Claims for the encompassing character of Agama Nunusaku meant that inter-religious marriages were said to be common in Ambon and west Seram during the 1970s and 1980s, though I have no statistics to suggest that they were in fact any more common in Maluku than in other parts of Indonesia. Whatever the figures tell us, children of such mixed marriages consequently had to address the issue as to which 
parental religion they should follow. I have had conversations with total strangers on board inter-island ferries that began with the question "Can I be both Christian and Muslim?" Conversion between religions and between religious sects within Christianity was relatively common in the period 1970-1985, often affected for instrumental rather than theological reasons. An acquaintance of mine in Amahai (let us call him "Om Piet", a small-time trader in south Seram and one-time RMS operative, imprisoned in 1975 for having a typewriter and RMS documents) had moved within the space of a few years between the GPM, the regular Pentecostalists and the Gereja Sidang-Sidang Jemaat Allah (Assembly of God), even though not all of these congregations viewed apostasy with equanimity, or as churches were equally tolerant of Agama Nunusaku heterodoxy. Such "serial conversion" also occurred within the Nuaulu community, for example Unsa Sounaue-ainakahata first became a Catholic (Ani) following an elopement with "Johannis Tuli", and then a Muslim (Abida) after marrying a Butonese migrant, and thereafter settled down with Beda (and reconverted to Catholicism) before migrating to Flores. Indeed it is common nowadays for Nuaulu families to contain siblings who owe allegiance to three different religious orientations (compare Keane 1995: 293).

Conversion from animism to Christianity within the Nuaulu community occurred steadily between 1970 and 1998. In 1970 there was one Christian household in the village of Rouhua, plus one single male convert. By 1998 there were upwards of 20 households and a church, located by the school. Conversion to Islam, by comparison, has always been less frequent than to Christianity, despite the historic and symbolic alliance with Sepa, and this is said to reflect the practical cultural sacrifices that conversion to Islam entails, for example male circumcision and dietary changes (Ellen 2004: 56). Nevertheless, there have been some high profile conversions since 1970, such as the eldest son of the village headman of Rouhua, who was later to become a Muslim religious teacher. Others married into converted Nuaulu families in the Muslim villages of Rutah and Sepa, thereby reinforcing clan links despite conversion. In the Nuaulu community during the 1960s and 1970s there was also in-marriage by Christian women from Nuelitetu and Hatuheno, in other words "reconversion" to animism, while individuals who had converted to either Christianity and Islam would regularly return to their natal villages to participate in rituals.

These cases of conversion are hardly Damascene and do not occur because those involved question or disbelieve adat, but for practical reasons, as when people marry out, seek otherwise unavailable opportunities in education or employment, or are trying to solve a problem created by the contravention of adat. Moreover, even when motivated by a convincing demonstration of theological and spiritual conviction, conversion cannot completely take place within a generation. Where an individual converts they rarely severe existing ties and obligations, and necessarily approach their new religion from within a context of existing cultural, cognitive, semantic, and emotional experiences. 
This is especially so where individuals are in a minority. In a sense, cultural assimilation was possible without complete conversion. Changing religious affiliation on marriage for Nuaulu is comparable to becoming subject to different adat rules as you move from one clan to another, but where you might also be subject to the adat of both clans when bridewealth remains unpaid. For example, Teliam Matoke had fought as an auxiliary in the RMS campaigns of the early 1950s and had the wounds to prove it. He subsequently converted to Islam and married a woman in the village of Rutah. This, however, did not prevent him returning to Rouhua periodically to participate in kahuae dances. On the whole, Nuaulu women who married Christians (or Muslims) move away from the village, while men who marry out remain.

In a few cases this simple instrumental model is inadequate. Conversion, for example, is sometimes a perceived solution to a string of misfortune, associated with the burden of monne. Thus Iako Matoke, the tuan tanah (landowner) and primus-inter-pares among Rouhua clan chiefs cut his hair, removed his red head cloth and converted to Islam in 1973 following an episode of illness said to be due to ancestral displeasure at his performance in ritual matters. He sought spiritual advice and healing in Tamilouw, but after a year had returned to animism, where he remained until his death. This is just as well, as if he had not, the vacancy for a crucial clan functionary would have posed considerable problems for effective ritual reproduction and might well have hastened the demise of Nuaulu traditionalism. All of this, in addition to Agama Nunusaku, might seem to give credence to Hefner's (1993: 4) point that conversion is: "[n]ot always an exclusivistic change of religious affiliation requiring the repudiation of previously held beliefs", and that:

When used in too bipolar a fashion, the categories of traditional and world religion are simplistic and reinforce certain prejudices of the putative rationality of the modern world and the irrational traditionalism of the premodern (Hefner 1993:4).

What makes shifting religious allegiances easier, as the view from Nunusaku and the metaphor of older and younger siblings attest strongly, is that when people convert it is not that one belief system is replacing another, but rather succeeding it (compare Keane 1995: 290).

Such apparent fluidity in crossing religious boundaries, though consistent with Agama Nunusaku rhetoric, however, can be deceptive. Conversion to other faiths has never been easy for Nuaulu for the same reason that some seek to escape it: namely the burden of monne and fear of ancestral retribution. There is also social resistance to conversion, since for many it represents a kind of weakness. Napuae, for example, once told me, in reference to Menai (who had converted following an episode in which he was not prepared to work on a sacred house) that those who convert are "lazy". Menai later reverted to animism.

Moreover, Nuaulu have developed clear notions as to acceptable forms of behaviour for those who have converted and remain in the community. Paulus (Poli) Matoke and his family who had been baptized into the GPM in 
1970 were required by clan chiefs to move out of the village of Rouhua if they were to keep a bible in the house. This was seen as a challenge to the ancestors, especially given strong Nuaulu notions of pollution related to spatial zonation. In this case it was regarded as acceptable for Paulus to build a new house a few metres outside the periphery of the village marked by the presence of menstruation huts. Individual Christians (such as Nathanial) continued to be permitted to live within the village at this time, but over time clan chiefs (and apparently the ancestors too) became more tolerant. By the 1980s I heard people say that the prohibition on bibles applied only to numa onate, that is sacred houses. Difficulties with Christianity have also occurred in relation to the Catholic mission in Masohi, who some Nuaulu have accused of coercing girls into becoming servants, and who in turn have intervened in Nuaulu affairs in cases of alleged incest and abuse. The unanticipated hazards of conversion were reinforced by the experience of the communal conflict and relocation in 1998, and Paulus - who had fled to Waraka - confided in me in 2003 that he did wonder what good conversion to Christianity had done him, though at his age he was not inclined to revert.

None of this, however, had much impact on the integrity of the animist population as a whole which because of exponential population growth had managed to ensure that population size was sufficient to reproduce the clans and rituals central to Nuaulu identity.

\section{PANCASILA, THE NEW ORDER, AND BEING "HINDU"}

An element of state ideology that became increasingly important under the New Order was Pancasila (Van Langenberg 1990: 123). This doctrine was a major ideological tool for national integration and social control and provided the context in which all law and civil affairs were to be conducted. Our concern here is with that part of Pancasila that prescribes that all Indonesians must belong to one of six religious affiliations: Christianity (Catholicism and Protestantism), Islam, Buddhism, Hinduism, and (more recently) Confucianism (Intan 2006). In Pancasila terms, religion excludes animism and adat, drawing on the notion of belum beragama (not yet with religion) to describe groups such as the Nuaulu. In this situation, and for other reasons, religion in the Pancasila sense has become strongly linked to the virtues of moral progress, development, including formal education, and a means of establishing citizenship (Spyer 1996: 193). As Kipp and Rogers (1987: 23) note, agama is maju (progressive, sophisticated), a point well exemplified in the case of Seram by Grzimek's (1991: 263-83) account of attitudes to economic change in Abio and Ahiolo. Certainly, it was in the interests of the Indonesian government to encourage further conversion as part of the process of integrating remote peoples within the state and of better effecting social control. The strong ideological linkage between religion and progress also provided the rationale for encouraging certain Christian missions to operate in Maluku (such as SIL, the Summer Institute of Linguistics), who's remit was agreed to be educational or development oriented. As Hefner (1993: 9) reminds 
us, it is because "world religions" are "driven by a redemptive vision [...] that they are perceived to have [...] the capacity to remake the world rather than passively accept it."

The Hinduism encompassed by Pancasila refers, of course, mainly to Balinese Hinduism and to a lesser extent to enclaves of Hindu devotion found elsewhere. ${ }^{12}$ However, as we have seen, Moluccan animists were quite commonly described in the colonial era literature as orang Hindu, a practice that has continued locally in the Moluccas and elsewhere well into the postcolonial period..$^{13}$ The usage was so entrenched in parts of Seram that local animists were often invited to state ceremonies (such as independence day, 17 Agustus) as official representatives of Agama Hindu, and in treating animists as Hindu they became, as it were, Pancasila-compliant. Nuaulu too, of the older generation, came to accept the description of what they do and believe as Agama Hindu, and this allowed them for a time to be accepted as a religion under the terms of the doctrine of Pancasila. Recognition and the conflation of Hindu Bali with orang Hindu therefore had unintended and unexpected consequences during the 1970s of granting privileges to Nuaulu in certain contexts (Ellen 1988b). The appellation has had other similar consequences more recently.

The cleverness of Pancasila has been that while promulgated as the underpinning ideology of a secular and culturally heterodox state, it has at the same time endorsed a limited and domesticated definition of religion as part of the glue that binds the state together. The situation on Seram resembled that evoked by Atkinson (1987: 172) in her characterization of Pancasila as being, paradoxically, a model of cultural inclusiveness, but one of exclusiveness in its application.

But in the context of outer island peripheries, those who fell outside Pancasila acceptability by being belum beragama became disloyal, administratively inconvenient and at worst a threat. However, I do not think Nuaulu have ever been branded as communists, as has been reported for elsewhere (Webb 1986). Apart from the protection afforded by the label "Hindu", and although not always such a pressing issue as it has become in recent years, Nuaulu have long regarded discrimination against them as having its ideological roots in the requirement to observe Pancasila (Ellen 2012: 3; see Tsing 1987). Nuaulu regularly complain that this results in them finding work (by which they mainly mean office work) only with difficulty. The same applies to

12 There is a certain irony in the way Balinese Hinduism became an acceptable conduit into Pancasila compliance. Being Hindu Bali had been a major problem for the Balinese themselves during the early years of Pancasila enforcement, given its polytheism and the absence of canonical written texts (Geertz 1964), but in 1962 Balinese Hinduism was finally admitted as an official religion (Geertz 1972).

13 Bartels (1979: 285) has noted the evidence for Hindu influence in pre-sixteenth century central Moluccas, including a reference by Rumphius (1910 (2): 991) to the worship of Hindu statuettes. Without denying this evidence, and recognizing that there might be folk-etymology at work here, it seems a rather tenuous basis for implying that this is why the term orang Hindu starts to appear in nineteenth century Dutch sources. 
recruitment to the armed services, access to tertiary education, and to obtaining government documents such as identity cards, marriage and birth certificates, and certificates of land entitlement.

By the 1980s Pancasila had become much more of an impediment for animists in the subdistrict of Amahai, and controversial in the religious politics of Indonesia more generally. Changes in its interpretation became evident, with a tightening-up under pressure from growing Islamization (Spyer 2002: 23). With Nuaulu more involved in education and in the wider labour market, they encountered stricter interpretations of Pancasila that prevented them from obtaining government jobs. It is a constant and very practical problem for young, modern Nuaulu who seek jobs in the army and civil service, and who wish to participate in civil society. For example, voting in elections requires an identity card that in turn depends on a declaration of religion. Their lack of official religious status is an obvious barrier to their progress.

\section{OTONOMI DAERAH AND THE MALUKU WARS}

The seeds of the problems that resulted in unprecedented levels of communal conflict between 1998 and 2002 had been sown in the second half of the New Order period. Heavy in-migration and increased resource extraction had provided the preconditions for tensions. Many of the incomers were unfamiliar with local adat and did not share the model of tolerance that Agama Nunusaku represented, and which might now be said to have failed (Bartels 2003). At the same time, education and improved communications had allowed Nuaulu to better articulate identity issues and frustration around access to employment. Pancasila, once seen as a liberalizing and integrating force in its flexible interpretation, was becoming increasing problematic. However, reformasi and otonomi daerah that followed the overthrow of the Suharto regime released new opportunities through a freer market in ideas as well as resources. For example, masyarakat terasing became komunitas adat terpencil (isolated adat communities), and Nuaulu could potentially benefit from a "rediscovery - or reinvention of pre-modern sources of order and identity" (Henley and Davidson 2007: 2).

The wider issues involved in the Moluccan disturbances that erupted in 1998, and which continued until about 2002, have been much discussed, and need not be repeated here. On Seram, the events mainly concerned conflict between Muslims and Christians, some loss of life, much population movement as people sort sanctuary, and destruction of physical infrastructure in places such as the kabupaten capital of Masohi. There was increasing polarization between Christians and Muslims, with Christian minorities fleeing to areas where Christians were in the majority, and Muslim minorities fleeing to the safety of areas with a Muslim majority. This, and the influence of Laskar Jihad and more Wahabi-influenced Muslim clerics challenged the commonalities of Agama Nunusaku.

By the end of 1999 and the beginning of 2000 most remaining Christians in Nuaulu villages of the Muslim desa of Sepa had fled, and established a separate 
settlement near Waraka, where there were also refugees from Nuelitetu ${ }^{14}$ and elsewhere. Others had sought refuge among earlier migrant Nuaulu families along the Wae Pia and Wae Siru, in the Teun, Nila, and Serua (hence TNS) subdistrict carved out in the 1990s to accommodate resettlers from the resource deprived islands of TNS. Here Christian Nuaulu remained despite conciliatory gestures from the Raja of Sepa. By 2003 the Waraka Christian settlement comprised 36 families and 146 individuals, technically refugees from Rouhua, but not all of which were ethnic Nuaulu.

For animist Nuaulu, connectedness with the market and administration and the benefits of modernization that they had steadily become accustomed to, were severely curtailed. The school and church had been destroyed, and so animist Nuaulu wishing to educate their children had once again to send them to Sepa. And the polarization between Christians and Muslims had consequences for the acceptability of their own beliefs and practices in the wider community. The kind of easy-going cultural hybridization associated with Teliam Matoke's visits to Rouhua from Rutah had become almost impossible. In the circumstances, Nuaulu were content to find themselves caught betwixt-and-between the dominant confessional groups and to describe themselves as "neutral". The period of religious conflict was a kind of interlude in which they were able to observe some of the advantages of not being embroiled in one kind of inter-communal violence, reinforcing autarky. With the outbreak of unrest between Maluku's Muslim and Christian populations their rituals, like the wearing of distinctive red turbans by adult males which had long been an ethnic marker (Ellen 1988b), began to actually afford some degree of protection against physical harassment. Animists in Rouhua were not affected directly, though those married into Christian or Muslim families were drawn in more than others. One sacred house was burned down in Kilo Duabelas, probably by aggrieved migrants from the village of Porto on Saparua, following the 1993 head-taking affair, but the house had been rebuilt by 2003.

From 2003 onwards, the inter-communal conflict eased and animist Nuaulu were able to resume a way of life they had been increasing adopting up until 1998. However, certain "facts on the ground" had changed: the Christians had moved to Waraka, and in general throughout Seram there had been a balkanization of settlement with Christians moving to predominantly Christian areas and Muslims to Muslim areas. Although by 2009 Christians were returning regularly to Rouhua to harvest tree crops, they did not resettle. Moreover, post-conflict reconstruction politics had set in with the formation of local NGOs, variously ELNUSA (Nuaulu Nusantara) for refugees from Hatuheno now in Wae Pia including some intermarried Nuaulu, and Yayasan Eklesia Nuaulu Manusela. In 2001 this latter controversially (in Rouhua) received funds from Mercy Corps for the distribution of non-food items to

14 The south coast village of Nuelitetu had, in fact, been sacked by local Muslims in 1996, and thereafter moved to Waraka. A request to the Raja of Sepa from its inhabitants to return to their previous location has not so far been granted. 
returnee families in various villages of the Tehoru subdistrict. Other outside aid (for example from SIL) was directed at the Christians who had fled, and at Yalahatan a mixed animist and Christian settlement where Christians had remained, resulting in no aid for animist Nuaulu. Indeed, animists found themselves in the strange position of giving handouts and sorting out the territorial affairs of their "poor Christian cousins". ${ }^{15}$

Paradoxically, access to education and the difficulties of deploying the Agama Nunusaku concept to their advantage persuaded Nuaulu to think even more of their beliefs and ritual practices in terms of an independent religion. The problems faced by Christian and Muslim converts during the troubles gave them a greater sense of security in the old beliefs, and the accompanying necessary economic self-reliance reinforced traditional practices. There were few conversions during the conflict period and immediately afterwards.

Nevertheless, the events might also have been thought to have had severe repercussions on the effective reproduction of ritual cycles. As the conflict unfolded from 1998 onwards, local populations that had previously been religiously mixed began to break away and move out. Caught in the middle, they were able to continue their rituals. Population displacement had an obvious impact on timing and on mobilizing potential participants from different settlements separated by militia and government activity, while market disruption affected the ability to acquire materials necessary for ritual and feasting. But contrary to what might be expected, the frequency - for example - of male puberty rituals (matahenne, the iconic meta-rituals that more than anything else have come to signify the distinctiveness of Nuaulu ritual among neighbouring peoples) did not decline between 1998 and 2003, but remained stable (Ellen 2012: 131-158, 301-305). Despite the conflict Nuaulu religious practices and identity not only survived intact, but demography ensured that ritual cycles were being continued as strongly as ever.

Throughout the communal disturbances, the government and moderate community organizations tried to use the rhetoric of common Moluccan culture to heal the wounds that had been inflicted. Pela, for example, was once again mythologized and reconfigured as part of peace and reconciliation discourse (Spyer 2002: 27). Indeed, some evoked the term "Alifuru" as a means of uniting indigenous Moluccans, Christian, or Muslim, as opposed to outsiders (Turner 2003: 254) - whether Laskar Jihad (Hasan 2002) or Butonese (Soselisa 2004: 75).

Moreover, with the post-conflict construction underway, the new freedoms introduced through reformasi politics could be further tested. By 2010, the issue of Nuaulu religious identity was once again being mentioned in the

15 By 2003 Christian Nuaulu in Waraka had purchased 100 hectares of dusun land (for plantations of clove and similar) from Sounaue-ainakahata Rouhua and from Matoke-pina (both clans located at Rouhua rather than at Kilo Duabelas). Although this involved a payment of 5, 000, 000 rupiah made on their behalf by the church, the transaction had been underpinned by invoking common Patalima allegiance and by an adat payment of plates and red cloth to satisfy the ancestral spirits. There had been no similar transaction earlier in cutting forest for impermanent swiddens, which was regarded as unproblematic. 
press (Tunny 2010) and displayed some familiar mixed experiences. Some schoolchildren were reported to have been able to avoid religious lessons with the support of more tolerant teachers, although Tuale Matoke (now chief of Nuanea), attending the College of Social and Political Sciences in Masohi under a less liberal interpretation of Pancasila, was forced to attend Bible classes and study Islam in order to successfully graduate. Similarly, since Kartu Tanda Penduduk or Kartu Tanda Pengenal (identity cards) requires an indication of "religion", Nuaulu cannot use them to register marriages. Tuale had registered as "Hindu" in line with pre-reformasi practice, though confusion surrounding the "Hindu" designation led in 2008 to Balinese Hindu priests being assigned to provide religious guidance for the increasing numbers of officially-reported "Hindu Nuaulu". As a result, Nuaulu complained and the attempt to "convert" Nuaulu to Hinduism stopped.

\section{DISCUSSION AND CONCLUSION}

The historical narrative that has unfolded in this paper highlights issues about how we conceptualize peoples who do not readily fit into official, scientific, theological, or folk-cultural categories. Nowadays, Nuaulu are compelled to think of their ritual practices and beliefs as "religion", and will use the Indonesian word agama to describe them. However, despite the desire to see what they do as religion, they also struggle with the fact that their religion diffuses throughout their cultural practice - for example in clan exchanges and subsistence activity - in a way that provides for no separate institutional space for what is generally understood as religion. Moreover, it is their distinctive ritual practices (especially puberty ceremonies) that define them as "Nuaulu" (Ellen 2012: 26), both in their own eyes and in those of others. Thus, when they convert they in a sense cease to be Nuaulu. These are hardly new issues, either in anthropology or among observers of Indonesian religious change. How do we describe peoples who adhere to local sets of beliefs and practices that are not parts of institutionalized domains of social activity of the kind we describe as "religion"? This is not simply a problem because in many cases local categories and words seldom map precisely on to this abstract semantic space, but because there is a practical issue when such people coexist with populations who have converted (sometimes several centuries previously) to institutionalized world religions. As we have seen, in the Dutch colonial literature (for example in lists of population numbers) such peoples are described as heathen (Heidenen), Alifuru (Alfoerisch), or even Hindu (see for instance Tichelman 1925). In Indonesian government documents and dictionaries, the terms animis, animisme (animism), and lain (other) are also found. In some areas those adhering to traditional religion are described as spirit-worshippers (as in Sumbanese agama marapu, see Hoskins 1987: 138), ancestor-worshipers, or "ritualists" (Keane 1995: 291, n9). The last of these might seem particularly appropriate in the Nuaulu context as it is their necessity to perform ritual that drives the compulsion to continue. Moreover, certain of their rituals have come to play an increasingly important 
role in their identity. Thus, Nuaulu are widely renowned for their puberty rituals, known in Ambonese Malay as kasimandi pinamou (for females) and adat cidako (for males). Their ritual practices, therefore, merge with their overall ethnic identity. But none of these descriptions are entirely satisfactory, partly because they essentialize what is a very diverse and complex set of beliefs and practices, but also because - as we have seen - some ontological and material features of all these definitions often persist when people convert, and indeed may become virtuous aspects of adat traditions in the context of what I am calling Agama Nunusaku.

The traditional religious systems of the Moluccas have been part of, or on the fringes of, the world system of commodities and ideas for a long time (Ellen 2012: 307). The Nuaulu first came into contact with the Dutch in the late seventeenth century, and we might reasonably assume that this was preceded by a long period of contact with other traders with whom they exchanged local products for textiles, ceramics, and metals. In the case of those animist populations and ritual systems that have survived there has been, therefore, a long period for familiarization and accommodation. Nuaulu, since the late seventeenth century, have sometimes responded to cultural contact through conversion, and acknowledgement of a broader consensual Agama Nunusaku embracing Christians, Muslims, and animists, had, until the events of 1998-2002, facilitated these shifts in ritual practice and belief. This strategy is what Geertz (1964), speaking of Bali, has called "internal conversion", that is, the adjustment of practices to a degree that makes them acceptable within the wider sphere of contemporary "Indonesian civil religion" (Atkinson 1987: 174). Although among the Nuaulu there has been nothing like the process of ritual rationalization that Geertz has described for Bali, or of the kind that others have described for different traditions elsewhere in Indonesia, and no "conceptual sorting out of agama from adat" (Kipp and Rodgers 1987: 23), there has clearly been a process of internal and very evident external negotiation, which indicates a movement in this direction. By 2003 Kaiisa - then government head of Rouhua - could assert in a conversation with me that "Nua-ulu" were not animis, and neither were they "Hindu", and that the ulu (conventionally meaning 'upriver') rather means dulu (formerly, ancient), and that what Nuaulu practiced was an agama sendiri (a religion by itself).

Such accommodation, however, has not halted the underlying continuing decline of traditional religious practices on Seram in general. The paradox faced by Nuaulu is that, despite their desire to remain separate and neutral in terms of religious politics, their children continue to marry Christians and Muslims, and are therefore marrying into potential demographic trouble. Consequently, despite some of the practical advantages of being neither Christian nor Muslim, we cannot entirely rule out accelerated collapse of the Nuaulu ritual system, as the completion and perpetuation of cycles becomes ever more difficult for material reasons, and as internal contradictions increase. Nuaulu are under pressure to alienate land as a means of income, and to delay ritual in order to prioritize economic activity. The consequence of both is an accumulation 
of dissatisfaction amongst the ancestors, reflected in illness and other forms of misfortune. Until now there has been a willingness to compromise in order to maintain a traditional way of life. The Nuaulu have - at least for the period of time I have been living amongst them - always stressed that they are now a religion of "plates and cloth". And yet, within the space of ten years, six individuals have been convicted for acts of violence that involved the removal of heads followed by the enactment of associated ritual processes. These contradictions and the accumulation of misfortune uncompensated for by ritual action might elsewhere provide the conditions for collapse. Komisi - the previous headman of Rouhua - mentioned to me in 1990 the possibility of pentutupan agama (closing-down or "putting the lid" on religion). The fact that this has not so far happened is I suspect largely due to the demographic trend that keeps reproducing large numbers of animist Nuaulu. This, more than anything else, is a vindication of the view that the reproduction of religious ideas, and the ritual cycles through which they are reinforced, are only viable where the supporting system of descent, alliance and exchange can continue; and this will only happen where the demography is compliant, and if exchanging clans can pool some of their jealously-guarded sovereignty. ${ }^{16}$

Although the Nuaulu are not involved, as far as I am aware, in the adat revitalization movement at a national level, such as represented by AMAN (Aliansi Masyarakat Adat Nusantara) founded in 1999, or in the indigenous peoples' movement that emerged from 1993 onwards (Moniaga 2007: 281), they have been influenced by general currents in national and media discourse and have a much better sense of their place in the world as a whole. Nuaulu recognize that "religious identity" is now much more important than all the other identities they are entangled with. Neither have Nuaulu, despite having felt the affects of environmental destruction, been directly involved with the advocacy of environmental and indigenous rights NGOs such as WAHLI and SKEPHI (Henley and Davidson 2007: 7), or with Baileo Maluku, which tend to have more support in Maluku Tenggara and the Lease islands (Moniaga 2007: 282). In the Nuaulu case we are not talking about adat revivalism at all, except in the demographic sense, but rather adat persistence.

Nuaulu are entangled is a multiplicity of identities projected on to them by others, some of which they are prepared to use when it is pragmatic for them to do so. They are not self-consciously pro-adat, but interpret their world through customary law and cultural assumptions, and "deploy" adat in the (sometimes) contradictory ways that seem right at the time (compare Li 2007). As Hefner (1993: 15) points out, "anthropologists [...] have succeeded in demonstrating that traditional modes of thought can be more flexible and systematic than Weberian characterizations of traditionalism would allow,"

16 Part of the problem is that Nuaulu have difficulty agreeing amongst themselves, between clans and between villages. The ia onate Kamama was widely recognized in 1990 as the Raja Nuaulu, but Rouhua do not recognize his authority because he cannot read. If they cannot agree politically to unify then this makes it difficult to present a unified religious front. Moreover, there remain many ritual differences between clans despite gradual convergence over the last 150 years. 
and that (p. 16) "the category of traditional religion, if it is to be useful at all, must not imply social organicism or uncritical conformism." We have seen here how Nuaulu religion, through adopting some of the institutional and representational features of "world religions", has been able to reinvent itself through the application of local knowledge, while the serendipity of demography has ensured its future - for the time being.

\section{ACKNOWLEDGMENTS}

The Nuaulu fieldwork underpinning this paper has been conducted over a series of field trips, beginning in 1970. The range of observations and data referred to are drawn from various experiences over this period, both in and outside the Nuaulu area. However, ESRC grant R000-239310 ("Frequency and periodicity in Nuaulu ritual reproduction"), which I held between 2001 and 2004, has provided me with a major opportunity to review and synthesize all matters pertaining to Nuaulu religious identity. Recent fieldwork in Maluku has been conducted under the auspices of Pattimura University Ambon within the terms of a Memorandum of Understanding with the University of Kent. I would like to thank Hunimora Neipane-tomoien in Nuaulu Lama for help with the year 2000 census figures, Yoni (Manioka) Sounaue, Wim Manuhutu, Pendeta A. Rangotwat, Pendeta Abraham Eyale Matoke for information regarding the Christian resettlement in Waraka, Watze Kampstra for access to video footage of interviews with Waraka refugees, and Hermien Soselisa, Bernard Sellato, Chris Hann, and Jennifer Cash for assistance and advice.

\section{REFERENCES}

Acciaioli, Greg. 1985. "Culture as art; From practice to spectacle in Indonesia”, Canberra Anthropology 8(1-2): 148-172.

Appadurai, Arjun. 1996. Modernity at large; Cultural dimensions of globalization. Minneapolis: University of Minnesota Press.

Atkinson, Jane Monnig. 1987. "Religions in dialogue; The construction of an Indonesian minority religion", in: Rita Smith Kipp and Susan Rodgers (eds), Indonesian religions in transition, pp. 171-186. Tucson: University of Arizona Press.

Atlas bahasa tanah Maluku. 1996. Atlas bahasa tanah Maluku. Ambon: Pusat pengkajian dan pengembangan Maluku, Universitas Pattimura and Summer Institute of Linguistics.

Bartels, Dieter. 1977. Guarding the invisible mountain; Intervillage alliances, religious syncretism, and ethnic identity among Ambonese Christians and Moslems in the Moluccas. PhD thesis, Cornell University, Ithaca, New York.

Bartels, Dieter. 1978. “Religious syncretism, semantic depletion, and secondary interpretation in Ambonese Islam and Christianity in the Moluccas", Kabar Seberang 4: 49-56.

Bartels, Dieter. 1979. "Magicians and politicians; Power, adaptive strategies, and syncretism in the central Moluccas", in: Gloria Davis (ed.), What is 
modern Indonesian culture?, pp. 282-299. Athens: Ohio University Center for International Studies.

Bartels, Dieter. 2003. "Your God is no longer mine; Moslem-Christian fratricide in the Central Moluccas (Indonesia) after a half-millennium of tolerant co-existence and ethnic unity", in: Sandra Pannell (ed.), A state of emergency; Violence, society, and the state in eastern Indonesia, pp. 128-153. Darwin: Northern Territory University Press.

Bleeker, P. 1856. Reis door de Minahassa en de Molukschen archipel; Gedaan in de maanden september en oktober 1855 in het gevolg van den Gouverneur Generaal Mr. A.J. Duymaer van Twist. Batavia: Lange.

Bouman, J.C. et al. 1960. The South Moluccas; Rebellious province or occupied state. Leiden: Sythoff.

Chauvel, Richard. 1990. Nationalists, soldiers, and separatists; The Ambonese Islands from colonialism to revolt, 1880-1950. Leiden: KITLV Press.

Collins, James T. 1982. "Linguistic research in Maluku; A report on recent fieldwork", Oceanic Linguistics 21: 73-146.

Deninger, Karl. 1914. "Morphologische Uebersicht der Insel Seran", Petermanns Mitteilungen 60: 16-18.

Donahue, B. and J.O. Habeck (eds). 2011. Reconstructing the house of culture; Community, self, and the makings of culture in Russia and beyond. Oxford: Berghahn.

Ellen, R.F. 1988a. "Social theory, ethnography, and the understanding of practical Islam in South-East Asia", in: M.B. Hooker (ed.), Islam in SouthEast Asia, pp. 50-91. Leiden: E.J. Brill.

Ellen, R.F. 1988b. "Ritual, identity, and the management of inter-ethnic relations on Seram", in: Henri J.M. Claessen and David S. Moyer (eds), Time past, time present, time future: Perspectives on Indonesian culture; Essays in honour of Professor P.E. de Josselin de Jong, pp. 117-135. Dordrecht/ Providence: Foris. [KITLV Verhandelingen 131.]

Ellen, R.F. 1999. “Forest knowledge, forest transformation; Political contingency, historical ecology, and the renegotiation of nature in central Seram", in: Tania Li (ed.), Transforming the Indonesian uplands; Marginality, power, and production, pp. 131-157. Amsterdam/Harwood. [Studies in Environmental Anthropology 4.]

Ellen, R.F. 2002. "Nuaulu head-taking; Negotiating the twin dangers of presentist and essentialist reconstructions", Social Anthropology 10(3): 281-301.

Ellen, R.F. 2003. On the edge of the Banda zone; Past and present in the social organization of a Moluccan trading network. Honolulu: University of Hawai'i Press.

Ellen, R.F. 2004. "Escalating socio-environmental stress and the preconditions for political instability in south Seram; The very special case of the Nuaulu", Cakalele; Maluku Research Journal 11: 41-64.

Ellen, R.F. 2012. Nuaulu religious practices; The frequency and reproduction of rituals in a Moluccan society. Leiden: KITLV Press. [KITLV Verhandelingen 283.] 
Fraassen, C. F. van. 1983. "Historical introduction", in: Polman, K. (ed.), The Central Moluccas; An annotated bibliography, pp. 1-59. Dordrecht: Foris. [KITLV Bibliographical Series 12.]

Galvão, António. 1971. A treatise on the Moluccas (c.1544); Probably the preliminary version of António Galvão's lost História das Moluccas. Edited, annotated, and translated by H. Th. Th. M. Jacobs. Rome: Jesuit Historical Institute. [First published 1544.]

Geertz, Clifford. 1964. "'Internal conversion' in contemporary Bali", in: J. Bastin and R. Roolvink (eds), Malayan and Indonesian studies presented to Sir Richard Winstedt, pp. 282-302. Oxford: Oxford University Press.

Geertz, Clifford. 1972. "Religious change and social order in Suharto's Indonesia", Asia 27 (Autumn): 62-84.

Gladney, D.C. 2003. Dislocating China; Muslims, minorities, and other subaltern subjects. Chicago: University of Chicago Press.

Grzimek, B.R.O. 1991. Social change on Seram; A study of ideologies of development in eastern Indonesia. PhD thesis, London School of Economics and Political Science, University of London.

Haar, B. ter. 1948. Adat law in Indonesia. New York: Institute of Pacific Relations. [Translated from the Dutch and edited by E. Adamson Hoebel and A. Arthur Schiller.]

Hasan, N. 2002. "Faith and politics; The rise of the Laskar Jihad in the era of transition in Indonesia", Indonesia 73: 145-169.

Hefner, Robert. 1993. "Introduction; World building and the rationality of conversion", in: Robert Hefner (ed.), Conversion to Christianity; Historical and anthropological perspectives on a great transformation, pp. 3-44. Berkeley: University of California Press.

Henley, D. and J.S. Davidson 2007. "Introduction; Radical conservatism - the protean politics of $a d a t^{\prime \prime}$, in: J. S. Davidson and D. Henley (eds), The revival of tradition in Indonesian politics; The deployment of adat from colonialism to indigenism, pp. 1-49. Routledge: London.

Hoëvell, G.W.W.C van. 1896. “Bijschrift bij de kaarten van Seran (vulgo Ceram)", Tijdschrift van het Koninklijk Nederlandsch Aardrijkskundig Genootschap 13: 508-532.

Holleman, J. F. (ed.) 1981. Van Vollenhoven on Indonesian adat law. Martinus Nijhoff: The Hague. [KITLV Translation Series 20.]

Hoskins, Janet. 1987. "Entering the bitter house; spirit worship and conversion in West Sumba", in: Rita Smith Kipp and Susan Rodgers (eds), Indonesian religions in transition, pp. 136-160. Tucson: University of Arizona Press.

Intan, B.F. 2006. "Public religion" and the Pancasila-based state of Indonesia; An ethical and sociological analysis. New York: Peter Lang. [American University Studies. Series VII. Theology and Religion.]

Kaam, B. van. 1977. The South Moluccans; Background to the train hijackings. London: Hurst.

Kantor Wilayah Kecamatan Seram Selatan. 1993. Statistik tahunan Seram Selatan. Amahai: Kantor Wilayah Kecamatan Seram Selatan. 
Keane, W. 1995. "Religious change and historical reflection in Anakalang, West Sumba, Indonesia", Journal of Southeast Asian Studies 26: 289-306.

Kelling, J. 1888. "Brief van J. Kelling uit Amahei", Orgaan Nederlandsche Zendingsvereeniging 28: 181-186, 30: 134-139.

Kennedy, R. 1955. Field notes on Indonesia: South Celebes, 1949-1950, Harold C. Conklin (ed.), New Haven: Human Relations Area Files.

Kipp, Rita Smith and Susan Rodgers. 1987. “Introduction; Indonesian religions in society", in: Rita Smith Kipp and Susan Rodgers (eds), Indonesian religions in transition, pp. 1-29. Tucson: University of Arizona Press.

Klinken, G. van. 2001. "The Maluku wars; Bringing society back in", Indonesia 71: 1-26.

Knaap, G.J. 1991. “A city of migrants; Kota Ambon at the end of the seventeenth century", Indonesia 51: 105-128.

Koentjaraningrat. 1967. “The village in Indonesia today", in: Koentjaraningrat (ed.), Villages in Indonesia, pp. 386-405. Ithaca, NY: Cornell University Press.

Krayer van Aalst, H. 1911. "Warasiwa”, De Macedoniër 15: 225-233.

Kruisheer, A. 1928. “Over West-Seram en over het verzet der Makahalastammen in 1914-1915", De Indische Gids 50(1): 233-252.

Langenberg, M. van. 1990. "New order state; Language, ideology, hegemony", in: A. Budiman (ed.), State and civil society in Indonesia, pp. 121-150. Melbourne: Monash Asia Institute.

Li, T. 2007. "Adat in Central Sulawesi; Contemporary deployments", in: J.S. Davidson and D. Henley (eds.), The revival of tradition in Indonesian politics; The deployment of adat from colonialism to indigenism, pp. 337-370. London: Routledge.

Moniaga, S. 2007. “From bumiputera to masyarakat adat; A long and confusing journey", in: J. S. Davidson and D. Henley (eds), The revival of tradition in Indonesian politics; The deployment of adat from colonialism to indigenism, pp. 275-294. London: Routledge.

Nader, L. 1991. "Harmony models and the construction of law", in: K. Avruch, P.W. Black, and J.A. Scimecca (eds), Conflict resolution; Cross-cultural perspectives, pp 41-59. New York: Greenwood Press.

Polman, K. 1982. The Central Moluccas; An annotated bibliography. Dordrecht: Foris. [KITLV Bibliographical Series 12.]

Rees, W.A. van. 1863. "De krijgstocht op Ceram in 1860", Koloniale Jaarboeken 3: 65-86, 129-163.

Rumphius, G. 1910 (1687). “De Ambonsche Historie”, Bijdragen tot de Taal-, Land-en Volkenkunde 64(1, 2). The Hague: Nijhoff.

Sachse, F.J.P. 1907. Het eiland Seran en zijne bewoners. Leiden: Brill.

Schulte Nordholt, H. 2002. "A genealogy of violence", in: F. Colombijn and J. Thomas Lindblad (eds), Roots of violence in Indonesia; Contemporary violence in historical perspective, pp. 33-61. Leiden: KITLV Press. [KITLV Verhandelingen 194.]

Schurhammer, G. 1963. Franz Xavier, sein Leben und seine Zeit, II. Bd. Asien (1541-1552), I. Halbb. Indien und Indonesien, 1541-1547. Freiburg-BaselWein. 
Schurhammer, G. 1980. Francis Xavier; His life, his times, Volume III, Indonesia and India, 1545-1549. Rome: Jesuit Historical Institute.

Scott. M. 2011. “The Makiran Underground Army; Kastom mysticism and ontology politics in South-east Solomon Islands", in: Edvard Hviding and Knut M. Rio (eds), Made in Oceania; Social movements, cultural heritage, and the state in the Pacific, pp. 195-222. Wantage: Sean Kingston Publishing.

Sebag-Montefiore, S. 2000. Prince of princes; The life of Potemkin. London: Weidenfeld and Nicolson.

Shay, A. 2002. Choreographic politics; State folk dance companies, representation and power. Middletown: Wesleyan University Press.

Smith, Douglas, (ed. and trans.). 2005. Love and conquest; Personal correspondence of Catherine the Great and Prince Grigory Potemkin. DeKalb: Northern Illinois University Press.

Soselisa, H.L. 2004. "Sagu salempeng tapata dua; Conflict and resource management in central Maluku", Cakalele 11: 65-80.

Spyer, P. 1996. "Serial conversion: religion, state, and number in Aru, eastern Indonesia", in: P. van der Veer (ed.), Conversion to modernities; The globalization of Christianity, pp. 171-98. New York, London: Routledge.

Spyer, P. 2000. The memory of trade; Modernity's entanglements on an eastern Indonesian island. Durham and London: Duke University Press.

Spyer, P. 2002. "Fire without smoke and other phantoms of Ambon's violence; Media effects, agency, and the work of imagination", Indonesia 74 (October): 21-36.

Tichelman, G.L. 1925. “De onderafdeeling Amahei, Seran”, Tijdschrift van het Koniklijk Nederlandsch Aardrijkskundig Genootschap 42: 653-724.

Tichelman, G.L. 1960. "Anthropological aspects”, in: J.C. Bouman et al., The South Moluccas; Rebellious province or occupied state, pp. 173-96. Leiden: Sythoff.

Tsing, A.T. 1987. "A rhetoric of centers in a religion of the periphery", in: Rita Smith Kipp and Susan Rodgers (eds), Indonesian religions in transition, pp. 187-210. Tucson: University of Arizona Press.

Tunny, M. Azis. 2010. "Noaulu people seek fair treatment", The Jakarta Post 05 November. [Http://www.thejakartapost.com/news/2010/11/05/ noaulu-peop, accessed 8-11-2010.]

Turner, K. 2003. "Myths and moral authority in Maluku: the case of Ambon", Asian Ethnicity 4(2): 241-263.

Valeri, V. 1980. "Notes on the meaning of marriage prestations among the Huaulu of Seram", in: J.J. Fox (ed.), The flow of life; Essays on eastern Indonesia, pp. 178-192. Cambridge, MA: Harvard University Press.

Valeri, V. 1989. "Reciprocal centers; the Siwa-Lima system in the central Moluccas", in: D. Maybury-Lewis and U. Almagor (eds), The attraction of opposites, pp. 117-141. Ann Arbor: University of Michigan Press.

Vries, S.J. de. 1875. “Kerkelijk rapport van den zendelingleeraar de Vries te Amahai (Ceram)", Tijdschrift voor Indische Taal-, Land-en Volkenkunde 22: 220-253. 
Webb, R.A.F. 1986. "The sickle and the cross; Christians and communists in Bali, Flores, Sumba, and Timor, 1965-67", Journal of Southeast Asian Studies 17(1): 94-112.

Zerner, C. 1994. "Through a green lens; The construction of customary environmental law and community in Indonesia's Maluku Islands", Law and Society Review 28(5): 1079-1122. 